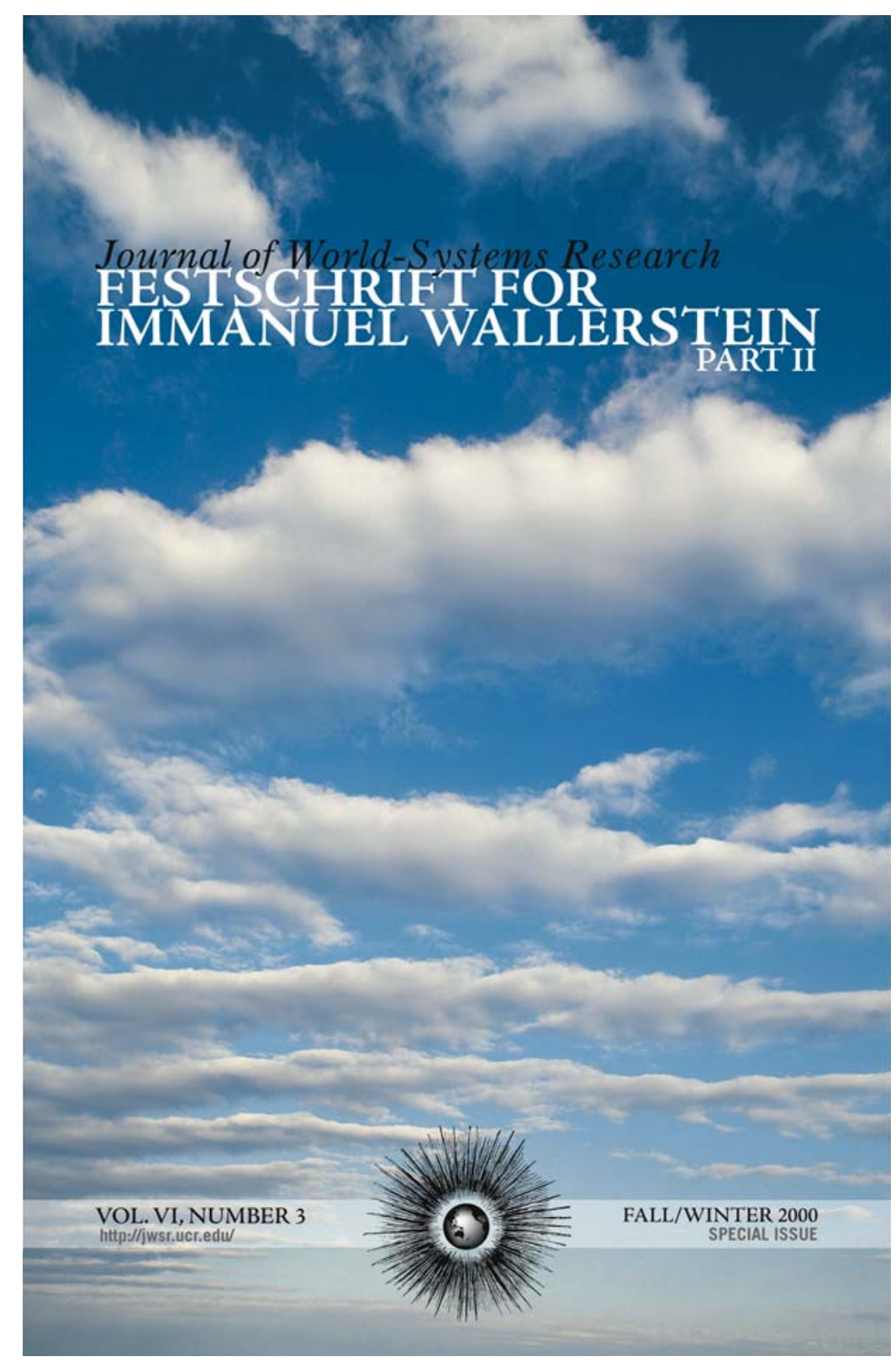

\title{
Economic Globalism and Political Universalism: Conflicting Issues?
}

Samir Amin

Tn the prevailing discourse, market and democracy are credited with such a strong unity it almost appears impossible to separate the two. The market is considered a manifest condition of democracy, the latter inexorably bound up with the former. Neither the concepts - nor the realities - of what is or what could be the market and democracy are questioned in this discourse. In the same manner, globalisation and universalism are conceived in the discourse as being practically synonymous. The "Global Village" constitutes one of the fashionable catch-phrases which, though bereft of meaning, bear witness to this confusion.

In this contribution, I will expatiate on the thesis that each of these dichotomies (market/democracy and globalisation/universalism) is more contradictory than complementary. The association of these two sets of issues, defined by an economic globalisation based on the market and a democratic political universalism, is as a result, utter nonsense which forces us to rethink the market, democracy and universalism within the perspective of a far-from-final history.

I.

The market is invoked in mainstream discourse just as supernatural forces are invoked elsewhere, forces to which individual human beings and society as a whole are supposedly subjected. They summon one to "believe in the market," because the market, and only the market, "reveals" the "true

Forum du Tiers Monde

BP 3501

Dakar

SENEGAL

ftm@syfed.refer.sn

JOURNAL OF WORLD-SYSTEMS RESEARCH, VI, 3, FALL/WINTER 2000, 582-622 Special Issue: Festchrift for Immanuel Wallerstein - Part II http://jwsr.ucr.edu 
values" of the hamburger and the automobile, of the square meter of living space in the metropolis, the hectare of rice field, the barrel of petrol, the exchange rate of the dollar, the work hour of the factory laborer in Asia or that of the Wall Street broker, the "true" price that must be paid to gain access to medical care, university education, to the web, etc.

The language through which the market is evoked is akin to fundamentalist interpretation of religion. Just as the God of fundamentalism created the entire universe, leaving us no choice but to submit to His will as revealed in the sacred text, the market commands the world; one must submit to its rule. The peculiar rationality of the market becomes that of the totality of social life.

This rationality is therefore not that of the emancipation of human beings and their society, it is that of submission to binding law. The market has thus become absolute, no longer the concrete network of trade relations classified under the modest category — no matter how important-labeled economic life. It is the principle which guides all human relations. One can then speak of the market of ideas, of political options (what a curious and despicable use of words), probably also of the market of the honor of politicians, like those of sex (both of which are alive and well-the Mafia knows how to use them). Ethics have disappeared.

It is the so-called calculation based on the market which we are offered as a common denominator proper to all human relations. Its implementation is based on such an astonishing principle of simplicity: for everything there is a supply (whose curve rises on the basis of price) and a demand (whose curve is descending). There is therefore a "true price" at their intersection. Supply and demand are independent of each other; nobody questions how they are formed in the real world and their subsequent interdependence. The sect of "pure" economists (that is to say unpolluted by "politics") was constituted to construct models of this curve, thus demonstrating that the market is self-regulatory and giving further legitimacy to its work by affirming that the equilibrium which it produces produces the best possible world. This is the very meaning of the "invisible hand." Have these efforts been successful? Certainly not, neither in theory nor in the practices which they inspire. ${ }^{1}$

How can the interactions of the rational behavior of elementary units be analyzed, further integrating expectations so as to produce a general equi- librium? Since the time of Walras, economics has been employed to no end since it has been demonstrated that it is impossible to derive the pattern of supply and demand curves from optimal behaviors (the Sonneschein theorem). Economists have resorted to narrating fairy tales. Fables credit animals with credible behavior and imagine the latter to achieve their objectives, which is to draw "the moral of the story." Since the time of the Robinsonnades, so-called pure economics has never been able to come out of this frame of generalization by analogy.

The fundamentalist believer- of God or the market - affirms in theory that it is not necessary for him to act freely, but only to submit, to wait for God (or the Market) to solve the problem. In practice he will remain a perpetual deviant because he acts nonetheless. That will not hold, the sectarians in question would say. We integrate expectations into the identification of rational behavior.

Arrow's model, the pride of pure economics, properly demonstrates that there is at least a general equilibrium in the hypothesis of perfect competition. The latter supposes that the famous auctioneer of Walras centralizes supplies and demands. Curiously, therefore, the model demonstrates that a central planner perfectly aware of the behaviors of the billions of actors operating in the market could make decisions that would produce the envisaged equilibrium. The model does not demonstrate that the market, as it really exists, can achieve this. It needs Big Brother to solve the puzzle.

Fortunately, there is no Big Brother. The system adjusts each time according to results produced by the effective actions of individuals who interact in the markets. The equilibrium, if achieved, will be as much the product of the process (which derives from chance) as the result of the rationality of actors.

Therefore, if fundamentalism is untenable in theory, it is much more so in practice. The pure economist sect pretends to construct an economy free of all facets of social reality such as the existence of states, the organized confrontation of social interests (social classes for example), the oligopolistic nature of the main producers' organization, the interplay of political, ideological and cultural forces, etc. They study economic life as the astrophysicist studies stars, denying what specifically separates social science from the sciences of nature: that society produces itself and that it is not manufactured by outside forces. However, they immediately disprove their own lies 
by introducing the concept of expectations, proving that the individual they sought to treat as an objective reality is the same active subject of his own history.

Moneytheism replaces monotheism. Fortunately, we are free to believe in other versions than that of the fundamentalists. One can believe in a God who allows human beings to make their history, and one can conceive of a regulated market. In reality, the market is always regulated, of course. The real option therefore is not regulation or deregulation, but what type of regulation and in whose interests?

I will not propose here a reading of the successive forms of regulation over the last two centuries, without which capitalist accumulation would have been impossible. I refer here to developments that the reader will find elsewhere. ${ }^{2}$ Each of these forms responded to challenges of the particular time and place, to the necessary social alliances through which the domination of capital was expressed, forcing the latter to adjust to the implied social imperatives. The reading of politics and history, in which fundamentalist sects have never shown interest since the truth has been revealed in its totality once and for all, makes it possible to understand the meaning and real impact of the market.

The victory of democracy over fascism, and of the peoples of Asia and Africa over colonialism, created, in the post Second World War era, conditions for transparent and efficient social regulation-for a limited time, as has always been the case in history. The historic compromise between capital and labor in countries of central capitalism, on the basis of which the "welfare state" was constructed, as well as the development project that I call national-populist in the Third World, have constituted the most recent stage of this long history. They are the real, or at least potential, forms of democratic regulation because they are socially transparent. The state appears then as the instrument for the implementation of these "social contracts." The state's intervention is not that of stupid and awkward bureaucrats bent on pursuing only ridiculous or hidden objectives, as presented in the discourse of rightist anarchism. Instead, it is the instrument for the affirmation of a mature society that knows what it wants.

Society is not governed by the principle of the anarchic conflict of individuals; it is not a jungle without laws (even the jungle or the Mafia are regulated by their own laws). Neither is it a long quiet stream of uni- versal harmony. It is the place of confrontations and compromises organized between incontrovertible social realities: nations, workers, enterprises, oligopolies, transnationals, etc. The compromises achieved between these interests - sometimes convergent, often divergent-define the mode of regulation that governs society, among others the mode of regulation of economic life, both at the national level and in international relations. Bretton Woods or fluctuating exchange rates are modes of regulation. But they express the victory of certain interests over others which are summoned to submit (and they either accept or reject it, in theory and in practice).

The universal anarchy/harmony utopia obviates reflection on the consideration of reality: modes of regulation that are always present. This is why the economy of contemporary one-sided thinking reduces the instruments of economic policy to two: budgetary policy and monetary policy. This is evidently not true. Other instruments, recognized or hidden, are in operation. There are always industrial policies, be they those of the state for example, charged with the task of supporting the establishment of stronger and more independent productive systems vis-à-vis the exterior, or be they the expressions of the strategies of private groups of industrialists or financiers themselves (and in this case one speaks, wrongly, of the absence of policies because they are not transparent). There are always social policies in fact, be they relatively favorable to workers (social security for example), or unfavorable to them. The flexibility of the labor market is not the absence of social policies, it is a social policy unilaterally regulated by the strongest - the employers. It is the implementation of the totality of these policies - recognized or not-which determines, among others, the state of the external balance, be it balanced or not. And since we live in a world of nations, states, and various currencies managed by various states, the search for a stable external balance is, to varying degrees, unavoidable. The mix of policies that I call regulation must take this into consideration. Whether this is achieved or not, whether it favors the interests of some or others, all constitute another series of problems.

What is known as deregulation is in fact nothing more than another form of regulation whose nature is hard to discern because it is unilateral. As a clear example, the WTO, a curious institution: if markets can really be deregulated, why the need for an institution assigned to regulate them? The WTO does regulate markets, while condoning, in the corridors, the 
dominant segments of capital (the transnationals) negotiating compromises between themselves. Being private business secrets, these regulations will simply be legitimized afterwards by states, called on to "rubber stamp these secret agreements." Opaque, the so-called "deregulation" is simply a shameful regulation and at the same time essentially non-democratic. The MAI (Multilateral Agreement on Investments) is even more cynical: it replaces the legislation of States, potentially democratic, with those of transnationals and above all erases the principles of the separation of powers; in the proposed courts of arbitration, the transnationals are both complainants and judges.

Whether transparent or opaque, regulation is always present. Markets can't exist without it, since the forces that operate in markets are the expressions of social relations, which the sect of pure economists have banished from sight. Markets (and the economy in general) are embedded in these relations. Karl Polanyi reminded us in $1944^{3}$ that the "liberalism" of the first half of the $20^{\text {th }}$ century had produced the two world wars and the Fascist drift. Before him, the classicists - from Smith to Ricardo, then Marx and, much later, Keynes - shared, beyond the divergence of their visions, methods and proposals, this recognition that economics is political.

Therefore, in the reality of the world, we do not have to deal with "markets" simply, but with markets for goods and services that are generally produced by private capitalist enterprises, the majority of them oligopolies, on the basis of defined relations of production (wage labor, labor which has a semblance of independence but which in fact is a kind of sub-contracting, etc.). In these relations the majority of human beings with only the strength of their muscles or brains to sell are alienated, in the sense that the history of which they are subjects and agents, appears to them as imposed from outside.

Similarly, in the reality of the world we do not have to deal with "natural resources" that can be treated as "goods" (commodified). These resources constitute the basis of reproduction not only of the material needs of the society but also of biological life. However, the rationality of the market, which is real but relative, is based in the short-term, that which, through the famous "devaluation of the future" does not go beyond a few years. Under these conditions the dictatorship of the market engenders the progressive and inevitable destruction of the natural basis of reproduction, the irrational consequence of the short-term rationality of market calculations.

In the reality of the world, we also have countries, states, nations (call them what you want), a reality we will probably live with for quite some time. A diversity of national or pluri-national currencies necessarily comes with this plurality of political power. However, mainstream economists assure us that since money is a commodity like any other, it carries a price tag-the equilibrium exchange rate-which assures external balance; and that the market, if deregulated, makes it possible to ascertain the "true price" of the currency. Yet none of the numerous Nobel prize laureates expert on this subject is capable of finding an answer to this simple question: what is the true price of the dollar expressed in yen that the market would have revealed to us? 80 or 380 yen? And, why, whatever the rate between these two extreme values between which the dollar fluctuated, has the external balance of the United States remained in deficit? In the same way, none of the most prominent economists has been able to find an answer to the question: what is the true exchange rate of the Euro and the dollar? Some have underscored a strong Euro of which they praise the advantages, the others support a weak Euro which they consider more useful. No one appears to be concerned with the "true price" of the new European currency. The currency is inseparable from power and market alienation pushed to their maximal point of abstraction, as Marx, and after him Polanyi, illustrated so well. The analysis shows that the supply of money is determined by demand. Besides, the central banks, for which some wish a neutral and independent management (by whom?), know that they do not have this magical power to fix the money supply. And they do not make it, because they can not make it, but act only partially and indirectly on the demand for currency, not on the supply, when choosing the interest rate.

External equilibrium can not be attained by way of the true exchange rate as revealed by the so-called deregulated market. If one pretends that this thing (the true exchange rate producing external equilibrium) exists and that one could know what it amounts to, one poses the wrong question, and, consequently, one can only provide a response bereft of any meaning. To the question: how is the true value of the dollar calculated? I answer: How is the true color of the logarithm known? A stupid question begs a stupid answer.

Therefore, in practice, what is being proposed? Deregulate to the maximum and you will approach this true value of your currency. In practice, 
for the weak economies in the global system, deregulation does not lead to external equilibrium. Then, devalue, we are told; or let your currency float and devalue your currency spontaneously. The wave of devaluation becomes infinite. The height of the irony: the more you devalue the more you move away from the purchasing power parity of which the defenders of the illusion (the exchange rate equilibrium) pretend constitutes the bottom line.

But who wins and who loses in this game? This question is avoided from the start- "this is not my domain," the economists concerned would say. And yet, visibly, there are winners and losers. Small winners: the horde of western tourists who can afford to pay for very inexpensive five-star hotels, beyond their reach at home. Big winners: the transnationals. Because it has been ordained, simultaneously, in the name of liberalisation, globalisation and privatisation, the sale of the juiciest pieces of the badly managed local productive systems of course, to the "efficient" transnationals. A national electricity company had constructed a network of production and distribution systems at enormous cost (in the past when the dollar was worth 100 local monetary units). Its juiciest segment (the one that is meant to serve the rich districts that can pay) is resold to a transnational while estimating that the 100 local monetary units are only worth ten American cents. And that is how the deal is struck. I call this the massive devaluation of the capital laboriously accumulated by the poor, a massive transfer of the value of the capital for the benefit of the rich. The pursuit of fantasy (the rate of equilibrium) has better served the real interests-those of the foreign buyer. The latter very well exists in reality. But the conventional economist is not aware of its existence, this is not his domain.

II.

Democracy is, like the market, a key and sacred word of the lexicon of modernity, one that has become so hegemonic it is now rarely problematized. The idea that the public makes of it, even cultivated, is based on fuzzy images, more or less precise: the agora of Athens, and Greek etymology of the word, Habeas Corpus, the human and citizens' rights declaration of 1789, the universal declaration of the human rights of 1948, multipartyism, elections, the separation of powers and the state of Law, etc. A long list to which the Asian and African nationalists, sensing that they had been forgotten by the enumeration of the mainstream media, have added the innumerable forms of dialogue in the management of villages in Africa and Asia (Islamic Choura, Indian panchayat). But neither one nor the otherbeyond the narrow circles of specialists-bothers to know how these institutions participate in the reproduction of a society or the type of society in question. Democracy is simply a good thing in itself.

The point of view I defend is firstly that we have to do with a concept and a historic modern reality, that is to say, constituted in relation to the formation of capitalism. I would say therefore that all forms of the organization of dialogue in the exercise of power in past societies do not have much to do with modern democracy, and that the Greek etymology of the word should not distort our understanding because power (democratic or not), ideology (and the content of the alienation that defines it) and economic life maintained in capitalist modernity are organized in a manner that does not have anything to do with the way it was in past societies. ${ }^{4}$

All philosophical systems throughout the ancient world were structured around a metaphysical form of this relation: there is a governing cosmic order which imposes itself on human beings and on their societies. The task, at best, was to seek out the divine commandments holding sway over them, or else to learn them through the utterances of prophets.

The modern era began with a philosophical break from that past. An era of freedom, but also of insecurity, began. Once political power was stripped of divine sanction, and the natural world was stripped of magical influences, the way to the free exercise of human reason was opened. Henceforth, humanity was called to the knowledge that human beings make their own history, that they can and even must do so, and that to do so they must choose. The modern world is defined by this rupture through which humanity escapes from the commandments of a cosmic order-or frees itself, rather, in the view of those who, like myself and many others, see this rupture as progress. For my part, it must be said that in the past metaphysical alienation was a necessary requirement for the reproduction of those precapitalist social systems which I have characterized as tributary, and the overstepping of this alienation is linked to the social system's qualitative transformation into a capitalist one. I insist on the word "overstepping" (dépassement) rather than "abolition," because I maintain that in its transhistorical, anthropological dimension the human being is a metaphysical animal. But that is a different question, not to be discussed here. 
For me there is no other definition of modernity, and modernity requires nothing more than the philosophical rupture to which I have referred. Thus we see that modernity can never be completed, never be closed. On the contrary, it opens onto the unknown, whose boundaries, though ultimately unattainable, are pushed ever further backward in step with the accumulation of our knowledge in regard to the social realm. Modernity is unending, but it takes on a succession of forms which vary according to the responses it offers to the challenges confronting society at each moment of its history.

The concept and practice of modern democracy find their place within this framework. To say that human beings make their own history is to propose an organized social frame which facilitates the creation of an emancipatory project. The latter in turn defines what we call modern democracy.

One then begins to see why democracy has nothing to do with the forms of social dialogue of past ages. The function of power, and the dialogue which underscores it, remains in the old systems based on the reading and interpretation of tradition, supposedly eternal since it is founded on divine laws. On the contrary, modern democracy fully embraces the right to invention. Herein lies all the meaning of the sign of equality which Enlightenment philosophy places between Reason and Emancipation.

The parliaments of the Ancien Régime in France, like the Choura of the Arabo-Islamic world as well as other institutions of dialogue proper to all ancient societies, were not democratic institutions in the modern sense of the term.

In Restoration France, for example, Joseph de Maistre proclaimed that the liberatory aspiration of the Revolution was a chimera to be abandoned, that the lawmaking madness of modern democracy was to be renounced because "only God is a legitimate lawgiver," and that the tradition of respect for God's law was to be dutifully obeyed at all times and in all places. Burke was not saying anything different from the Islamic fundamentalists of today. The sentence written by Joseph de Maistre could have been signed yesterday by Ayatollah Khomeini and today by Cheikh el Azhar. In all the instances the relation between Reason (and the necessary democracy to attain it) and Emancipation is shattered.

The proposition that humanity makes its own history represented the birth process of modernity and defined the field of inquiry for social thought, but it suggested no answers to such inquiry. Who is the active agent of this history: all individuals, or only some of them? Social classes? Various communities and groups with their own unique qualities and statuses? Nations? Societies organized as political states? How is this history made? What real factors do these agents put to work? What strategies do they adopt, and why? How, and according to what criteria, do they judge success? What real conditions are transformed by their activities? To what extent do those transformations correspond to the goals of their authors, and to what extent do they diverge? All these questions remain perpetually open. They simply remind us that modernity is a permanently moving process, not a system closed and defined once and for all.

The development of modern democracy, which came in response to these issues, therefore has a history. This response crystallizes first of all in the capitalist social project which defines the subject of this history: the bourgeois who is simultaneously the citizen and the entrepreneur. This double quality breeds a strict separation which bourgeois modernity imposes between the political domain, guided by the principles of democracy, and economics as managed by private property, free enterprise and market competition.

The democracy in question is therefore exclusively a political democracy. It gradually proclaimed its principles (the rights of the individual, freedom of expression, election, the separation of powers) and invented institutions permitting its rule (legislative houses, governments chosen by electoral majority, independent judiciary etc.). It defined the citizen with the freedom to exercise these rights. This citizen was first and foremost a man; it was only much later, in the most advanced modern democracies, that similar rights were to be attained by women (rights still not fully awarded de facto). It was only after prolonged struggle by the working classes that universal suffrage was extended. As can be seen, the equation market equals democracy does not have much to do with an abstracted view of history; modern democracy was only achieved through the active struggles of the victims of the market.

Modern bourgeois thinking does not at first recognize the contradiction inherent to the strict separation of market and democracy. On the contrary, they are viewed as two distinct dimensions of emancipation, that of the citizen and that of the entrepreneur (and the two characters are most often found in the same individual). The idea that the other individuals who are 
neither citizens nor entrepreneurs - women, workers - should enjoy rights is still a stranger. Thus, it is no surprise to find that the leaders of American independence turned out to be slave owners; they proclaimed themselves democrats as well. Thus, it is not surprising that the first modern democratic legislation forbade "workers' coalitions" and strikes, in such a way as to strictly separate the principles of democratic governance of politics and those of economic management through capital, enterprise and market.

The history of democratic progress continued precisely through the affirmation and conquest of new rights, social rights which challenged the unilateral management of the economy by the market. Here again it was necessary to wait quite a while before these new rights emerged. $U p$ to the Second World War, they continued to remain practically limited to a few rights for workers' organizations (free trade unions, right to strike) and light labor laws. It was only after the war that the working class was able to win - thanks to the defeat of fascism - a political and social legitimacy that it never enjoyed before. It was only then that the "welfare state" was conceived of and constructed, producing a new form of social regulation of the market.

It is useful to return to the theoretical issue implicit in our analysis in order to complete the debate which preceded concerning the concept of democracy - to wit, the meaning of the proposition that the human being, individually and collectively, makes his own history. It will be seen at the same time how the separation of the realms of democracy and the market constitutes a fundamental contradiction of the capitalist project.

To overstep metaphysics is thus to assert that there is a dichotomy between nature and society, and by that fact to reject any confusion between the domain governed by natural laws (whose discovery is the business of the natural sciences) and that governed by "social" laws. Recognizing that such laws have a status different from that of natural laws (because humanity makes its own history), I now, as always, insist on this distinction, which is a subject of perpetual discussion. It is not accepted by those for whom the natural sciences represent the model for the social sciences. Because I consider such an approximation to be both a distortion and an impossibility, I have suggested that we should speak of social thought rather than social science, without for a moment conceding that this terminology implies that a scientific world view is indispensable in the investigation of social thought.
At every instant, modern social thought is torn between its aspiration to treat human beings as the free authors of their own history and its recognition that they are subject to seemingly objective laws comparable to the laws of nature. Under capitalism, the dominance of economic factors is expressed as the autonomy of economic forces. Like natural forces, these act as realities subject to objective laws. In the dominant discourse there is a perpetual insistence on a supposedly unavoidable submission to these notorious economic laws (which vulgarizing rhetoric encapsulates in the phrase "the market"). In vaguer and often cruder forms of this rhetoric, reference is made to laws of nature, and even to a "state of nature," to which people would be as subject as they are to objective forces. Recall, however, that the Enlightenment modernity defined itself, with its call to escape from supposedly natural laws and to give full authority to the lawmaking citizen. As we will see, retrogression toward submission to these alleged demands of nature is always lurking in the recesses of bourgeois thought. From nineteenth-century social Darwinism to aggressive contemporary insistence on genetic and "neurological" explanations of social phenomena, this deviant conceit is perpetually present. Yet it is forcefully expressed only under certain conditions that must be specified.

The movement of history is not predetermined. It does not proceed linearly and unidirectionally. It is comprised of moments of advance in some direction, of hesitations, of retreats, of blind alleys, of choices at forking pathways.

During periods of tranquil progress it is always very tempting to think of the historical process in linear terms. These are periods which the political economy of the system interprets as phases of accumulation ensuring reproduction of the social relations primary to the system. During those moments, history seems to be going, naturally and inevitably, in a known direction. Those are moments during which social thought seems capable of producing powerful and coherent doctrines, those of the "grand narratives" (such as the bourgeois democratic project, the socialist project, or nation-building projects) which current social thought, in deep crisis, treats as objects of ridicule. There was no difficulty in giving each special branch of knowledge, as it applied to its own plot in the field of social reality, its appropriate place within such an architectonic doctrine.

On the other hand, when the social equilibria that hitherto ensured 
the calm reproduction of society have turned topsy turvy, when no one can foresee the direction in which society will move once its equilibria have been restored, the crisis also becomes manifest in the collapse of those big, reassuring intellectual structures. Their weak points become yawning gaps. Such periods are then marked by the fragmentation of social thought, and this fragmentation provides fodder for wayward conceits that direct it away from its needed reconstruction.

My interpretation of contemporary history treats it as having moved out of a period of the former sort which fell apart in the current crisis.

Therefore, is modernity outmoded, as is complacently uttered in current fashionable discourse? Not in the least. For if modernity simply means that human beings make their own history, then it is a long way from becoming outlived. Undoubtedly, in times of deep crisis, like the present, there is a great temptation to go back to a pre-modern stance and claim that while human beings believe that they make their own history, in reality history takes place quite apart from their activity. In other words, there is a temptation to claim that what happens is unknown and unpredictable, let alone influenced through constructive and consequential action, and accordingly to suggest falling back on the unambiguous stance of trying to manage this meaningless history as well as possible. To manage as well as possible, then, means the democratic management of pluralism at the grass-roots level, the organization of so-called "conviviality," the improvement of this or that aspect of social life. The counterpart to this is acceptance of the essential features of the established system, including the rule that the market dominates everything-i.e., capitalist political economy. The motives leading to these conclusions are understandable: they stem from disarray consequent to the exhaustion and even collapse of the great projects marking the preceding stage of history, especially the socialist project but also that of the nation-state and various others. But to understand these motives is not the same thing as to believe that this situation might last eternally, as is proclaimed in the "end of history" thesis.

The critique called post-modernist thus fails to see that modernity, always incomplete, is today confronted with a challenge, not to renounce its fundamental principle but to move ahead in its implementation.

Preceding the postmodernist propositions is an extensive rhetoric asserting "the failure of modernity." The least that can be said on the topic is that this superficial discourse has no analytic foundation whatsoever. The modern epoch is also the epoch of humanity's greatest achievements, accomplished at a pace immeasurably greater than that which marked pre-modern times. Modernity achieved enormous progress in material production and scientific knowledge; likewise, progress of democracy despite its limits and occasional setbacks; social progress, also despite its limits; and even ethical progress. The idea that each human life is irreplaceable, the idea of happiness, the idea of individuality irreducible to membership in a familial or ethnic collectivity-these are all modern ideas. Certainly these results of progress - and I have no qualms with using that currently unfashionable word-did not come about through continuous movement along a straight line; they had to be won, they are always threatened, and there are setbacks which are always accompanied by enormous crimes. But this is no reason to throw out the baby with the bath water and to mutter that "things used to be better." Nor is it a reason to simply say that because of "failures" we must give up on the foolhardy struggle to go forward and instead be content to simply cope with the present reality. That would be to take a leap which I consider neither necessary nor useful.

Modernity remains an unfinished project, and it will be so as long as the human race continues to exist. Currently, the fundamental obstacle setting its limits is still defined by the social relationships specific to capitalism. What the postmodernists refuse to see is that modernity can progress further only by going beyond capitalism. Unfortunately this possibility seems inaccessible at the present moment. For the "failures" of modernity and the aggravation of conflict which has brought with it a wave of violencerecognition of which is the source of the postmodernist thesis-are results of the evolution of that same capitalism and signs that it has reached the end of the historical path at whose earlier stages it could still, despite its specific contradictions, appear synonymous with progress. Today the choice of "socialism or barbarism" is truly the choice confronting the human race.

Postmodernism draws no distinctions in its indictment of the various "master narratives." It rejects the concept of capitalism which, like Enlightenment, it treats as synonymous with reason and modernity. Undoubtedly, all these great narratives are based on a single abstract notion, that of emancipation - another way of saying that human beings make their own history-and accordingly they seek to formulate concretely liberatory projects. 
The Enlightenment established that the concepts of reason and emancipation are closely corresponding, even synonymous, with each other: reason becomes meaningless if it is not put to the service of emancipation, and the latter is impossible if it is not based on the former. Nevertheless, this common denominator is not a sufficient basis to mix up the bourgeois-democratic project with the socialist project, whose objective is precisely the overstepping of the limits of the bourgeois-democratic project. The bourgeois-democratic project was liberatory of the citizen and the individual through the establishment of a law-governed state and universal education, but was deferential to such fundamental requirements of capitalism as property, entrepreneurialism, wage labor, and the laws of the market. Nor can one be content with mentioning the failures of each project (mass culture and the associated manipulation of democratic process under capitalism, the deviant course that drove the Soviet project onto the rocks) to justify the conclusion that it is no longer possible to give meaning to history.

The crisis of democracy is today a major issue demanding our attention. The combination of two series of evolutions, which merge as one in the short term, today gives room for the permanent contradiction in capitalism between the expansion and deepening of democracy and the unilateral dictatorship of the market.

We are in fact living in times characterized by a disequilibrium in the relations of social forces to the benefit of capital, to the detriment of labor. A temporary product of the erosion of the post-war systems of regulation, this imbalance intensifies the utopia of "deregulation," that is to say, the onesided regulation by capital. In this situation social rights conquered after a hard struggle by the popular majority are questioned. Democracy returns to its bourgeois origin: that of sole political management while economics is handed over to the dictates and vagaries of the market. What is produced is what I call a "low intensity democracy." The citizen (and today it is everybody) can vote freely for the right or left. This is no longer of any importance, let alone effect, because his future as worker (or as an unemployed person) will be decided elsewhere, in the "market."

The vote loses its meaning, its impact, resulting in the crisis of democracy. In countries where people believed the latter finally entrenched, it wobbles: the abstention of the majority of the electorate in the United States (and the poorest half is not by happenstance) as events have proved. Is the devaluation of what is called the political class in Europe not a sign of the same dangerous erosion? In the Third World, manifestations of this crisis are even more violent. The erosion of societal, national populist projects has no doubt found an opening in the desirable recognition of the virtues of free expression and political pluralism. But this opening coincides with a degradation of the social situation including the imposed model of globalisation, which will be examined later. Also, the process of political democratization had hardly gained momentum before it quickly lost legitimacy in the eyes of the popular majority. What can be expected of this fancy pluralism, electoral travesty and the weak powers they produce? Does the escalation of religious fundamentalism and ethnic strife not already prove that disaster is not far away?

Nonetheless, this serious crisis coincides with a new leap in the development of productive forces. The rapid progress of science and technology has already quickened what I call the necessary withering away of the dictate of value, which is to say the market. Globalisation, which I take up now, aggravates this major contradiction of capitalism, catapulting the explosive market/democracy conflict to levels of unprecedented violence.

III.

Globalisation has equally become a "catchword" so much abused in popular discourse that one is no longer sure of its real meaning. Taken in its most ordinary sense- the existence of significant relations between the various regions-globalisation is as old as the world, even if it is agreed that these relations today are considerably more crucial than in the past. But it is certainly even more important to identify the specific characteristics of each of the successive phases of this very long history of globalisation, to analyze its mechanisms, linking the successive forms of globalisation to the social systems of regions in mutual relations.

There existed - at least for the old world of Eurasia and Africa-a system of globalisation that I described and analyzed over the long duration of two millennia, from $500 \mathrm{BC}$ to $1500 \mathrm{AD} .^{5}$ The so-called silk roads, transfer of technologies and the spread of religions, testify to the reality of this ancient globalisation. When Vasco de Gama landed on the coast of India in Calicut in 1498, he was surprised to find Christians there. It is known that the Uigurs were Nestorians before being converted to Islam, that Islam 
traveled to China and Indonesia, that Buddhism came all the way from the Himalayas to conquer Mongolia, China (for a time), Japan, Sri Lanka and countries of Southeast Asia, that Alexander the Great, then Christians and Moslems found it in Afghanistan.

The globalisation in question - which did not integrate so-called PreColumbian America-was very different in the logic of its working from that which subsequently became capitalist modernity. The three "centers" of the old globalisation (the Chinese, Indian, and Middle-Eastern) accounted for 80 percent of the population of the globe. This globalisation was not polarizing in the sense that the development gaps between the various regions were, for the most part, very modest, perhaps not exceeding the ratio of two to one. Furthermore, little stood in the way of upward mobility. It is instructive that the greater part of Europe, which until around the year 1000 was on the periphery of the global system of the time, was able, over a remarkably short period of time - three centuries - to "catch up" to, and even "overtake," the old centers.

In its modern form, globalisation developed after the industrial revolution which, between the 18th and the beginning of the 19th century, marked the beginning of full fledged capitalism. The mercantilist transition, between 1500 and 1800, can be interpreted from this point of view as the fight between the old (feudal) mode of production and the new (capitalist) one, and also as the fight between the old global system (which swung between three centers: Chinese, Indian and Oriental) and the new system which integrated the Americas and organized the ascendant Atlantic-European center. I will not dwell on this crucial turning point which I have discussed elsewhere. ${ }^{6}$

The new globalisation - that of capitalism-is polarising. In two centuries, from 1800 to the end of our century, it has been able to reduce the population of the centers of the system-whose frontiers have not changed much and which generally embraces the contemporary "Triad" (the United States, Canada, Europe, Japan) - to 20 percent of the population of the planet. The developmental gap between these centers and the vast regions of the world which have become their satellites, has continued over the last two centuries, to the point that the ratio mentioned earlier (which was twoto-one in 1800) is sixty-to-one today. The polarization that is characteristic of modern globalisation is definitely phenomenal, without precedent in the history of humanity.
The key question this raises is whether this polarization is immanent to the global expansion of capitalism, that is to say, produced by its governing internal logic, or if it is only the result of various concrete, multiple and specific conditions having all, as if by chance, operated in the same direction, therefore making it impossible to catch up. The prevailing discourse does not broach this issue, resting content in repeating ad nauseam that "globalisation offers an opportunity."

As a counterpoint, I advance the thesis that polarization is immanent to the global expansion of capital. This is because the "world market" in question remains deeply unbalanced by the single fact that it remains truncated. Constantly widening its commercial dimension (trade in goods and services) and the international transfer of capital, this market remains segmented both with regard to labor and international migrations of workers which remain subject to controls. On its own, this truncated nature of the world market is bound to engender polarization independent of the thousand and one concrete specific conditions that, according to conjunctures and policies, can either spur the acceleration of growth here, or slow it down elsewhere. ${ }^{7}$ Liberal discourse pretends to be unaware of this reality and, as a result, remains inconsistent. A truly coherent liberal should insist on the opening of borders in every dimension. Then, trade, capital flows and migration of workers would create conditions for the homogenization at the world level, of an authentic globalisation of the economy. Marx and Engels thought in 1848 that the bourgeoisie would make it and would have the courage to carry on to the end of its project. They certainly overestimated the historic revolutionary role of this class. The end result was therefore a globalisation of capital and not of the economy, which, on the contrary, differentiates itself in the center/periphery dichotomy that continues to worsen.

The progressive construction of polarization in the real existing world of capitalism also has its own history in which one can recognize stages of its consolidation. During one-and-a-half centuries —from 1800 to 1950 - this polarization was practically synonymous with the industrialised/nonindustrialised divide, a duality challenged after the Second World War. The Russian revolution from 1917, then that of China, sought both "to catch up" (through industrialisation) as well as construct other social relations inspired by historic Marxist socialism. The political successes of national liberation movements in Asia and Africa, and the Latin American "desarollismo" in 
turn, imposed an overhaul of the past scheme of polarization. All are expressions of the revolt of peoples of the periphery, victims of the polarizing capitalist globalisation. These are expressions in tandem with more or less radical historical movements in association with more or less revolutionary internal social changes with the objective of accelerating modernization and industrialization.

This string of major changes largely took the center stage of history during two-thirds of our century, testifying to the dominant character of the polarization of modern globalisation. This evidence-for me-has nonetheless been permanently forgotten in conventional social thinking, and underestimated, to say the least, in the critical thinking of socialisms and even of historical Marxism.

Dominant capital has been forced by this new relation between social forces more favorable (or less unfavorable) to peoples of the periphery "to adjust." It did so with success to the point that it has been able "to reintegrate" into the global system societies which, to varying degrees, had attempted to make themselves autonomous. This is a way of explaining the gradual erosion of the soviet and national populist models. Much closer to the concept of a "capitalism without capitalists" (with regard to the former USSR) or "state capitalism" (with regard to countries of the Third World) than to that of original socialism, the models in question attained their historic limits after having fulfilled their real functions of transition leading to "normal" capitalism.

But the societies in question reintegrated into capitalist globalisation without transforming themselves into real new centers equivalent to the historic centers that were always a significant element in their models. The explanation of this reality is certainly complex, varying from one country at a given time to another, and could be subjected to scurrilous generalizations. The internal social, political and ideological dynamics proper to these societies certainly share a major responsibility in this history (or more precisely these particular histories). But I will assert that, beyond these concrete and diverse conditions, two major realities dominated the scene of this history.

The first concerns the shift of the center of gravity of the forces that produce and reproduce polarization. The previous form was industry, which has subsequently been replaced. In its place, I argue that advantages which allow the historic centers (the triad for short) to maintain their dominant positions (in spite of the industrialization of the peripheries) is located in what I called the "five monopolies": ${ }^{8}$ technological initiative, the control of financial flows at the international level (the most internationalized facet of capital), access to the natural resources of the entire planet, control of the means of information and communication, and, last but not least, monopoly of weapons of mass destruction.

Through the use of these five monopolies the triad puts industries of the periphery in positions of sub-contractors, similar to what was, at the dawn of capitalism, the system of putting craftsmen at the mercy of mercantile capital. In the spirit of this analysis, what I called the law of globalised value has passed through successive forms, each specific to the particular phases of polarizing globalisation: unequal trade to the phase of the industrial divide, giving way to new forms of extraction of the surplus produced in the "globalised" peripheries. The case of Korea, to which I will return, perhaps illustrates better than any other the nature of the dynamics of the new polarization. This analysis, of course, is in contrast to the rosy "success stories" in which the World Bank specializes.

The second has to do with the persistence of a "reserve" labor force that globalisation of the periphery (including socialist states) was unable to absorb. The concept that I propose to consider here is founded on a distinction between two categories of workers: those in efficient, modern forms of production who are, as a result, competitive, and those who are excluded, namely workers in sectors with low productivity. The distinction is certainly relative and sketchy, but significant. ${ }^{9}$

Historical capitalism was able, in these advanced centers (the triad), to gradually absorb the reserve into what I call "the active army." The thesis of the globalisation of developing countries through parallel labor absorption became classic with the work of Arthur Lewis. ${ }^{10}$ The conventional thinking - that of the World Bank, for example-never went beyond this. Yet, the facts demonstrate that this absorption is impossible within the context of the prevailing logic governing the accumulation of capital for reasons that are almost obvious. As long as productive forces develop, modernization requires a relative increase of capital and decrease of manpower. This inability of capitalism to absorb a "reserve" that has become a larger proportion of the global population defines the historical limit of this social system, the irrationality of its rationality. 
By examining the advance of peripheral societies in industrializing, and the proportion of their mass of "reserve," one gets a striking picture of the magnitude of the challenge facing humanity as a result of capitalist globalisation and the diversity of the forms in which it is expressed.

This challenge also concerns the centers themselves. A reserve army is indeed on the road of reconstitution here for twenty years or so (the unemployed, the poor, the excluded and the marginalized). I will not intervene here in the debate on this set of problems: ${ }^{11}$ products of "transitory" changes (even though, persistent over several decades and perhaps affecting a quarter or a third of the population, as could possibly be the case in Great Britain, the "problem" already embracing dramatic dimensions), or a trend that is bound to worsen by reason of the nature of contemporary scientific and technological revolution?

The kind of revolutions that shook the peripheries of the system during the 20th century, and particularly during its second half, their radical nature, led to the constitution of three layers of nations more or less engaged in modernization and industrialization.

The first layer no doubt embraces all the countries called socialist or formerly socialist: the USSR, Eastern Europe, China; South Korea and Taiwan, as well as, to a lesser degree, India and the major countries of Latin America-Brazil and Mexico. These countries entered the industrial revolution, in the sense that they constructed some national industrial productive systems, as a result of which they are either effectively competitive (Korea is the best example) or at least are potentially so (without however, excluding possible involution in real history).

However, none of them has been able to reduce its reserve army in the same proportions to what this reduction was in the centers in their analogous stages of development. It seems reasonable to estimate this reserve at 40 percent for Russia, more for Brazil and Mexico, and at a much higher proportion (in the neighborhood of 70 to 80 percent) for India or China. Korea and Taiwan are perhaps the two exceptions to the rule, which can be explained by some exceptional local and international conditions.

The second layer consists of countries where industries have been established largely by transnational capital, but where it is difficult to identify a national productive system. Some of these dispersed units can be competitive, others not, and the local system as whole is not, or is far from becoming, so. It is difficult to say that these countries have "achieved" their industrial revolution. I group in this category countries of south-east Asia whose capitalism is subject to qualification, not without reason, of "proxy capitalism" (or "ersatz capitalism"), ${ }^{12}$ the Arab countries (Morocco, Algeria, Tunisia, Egypt, Syria, Iraq), South Africa, Turkey and Iran, and some countries of Latin America. Considering a lot of singular data for each of these countries, the aggregate reserve varies between 50 and 70 percent of the population.

The third layer contains countries that have not yet industrialized (subSahara Africa, the Caribbean, and some west Asian countries). In these countries the aggregate reserve nearly constitutes the totality of the population.

It will be noticed that my classification is silent on some of the oil producing or mining states whose rentier economy does give the appearance of wealth (in terms of income per capita) simply because they are sparsely populated. Like the American Protectorates of the Gulf, these countries are, in spite of their financial clout, passive participants in the world system, in reality just as "marginal" from this point of view as countries of the third group. Marginalisation, which I have defined in terms of the passive position occupied in the world-system is not synonymous with poverty. This inter-relationship is very evidently predominant, but there are exceptionsthe marginalized "rich."

In fact, only countries of the first order of the periphery try to impose themselves as active participants of the world system, to force centers of the triad to adjust to the exigencies of their development. As we will see, this ambition is bound to occupy a central position in future conflicts.

The analysis that I propose here of modern globalisation seen in its economic dimension, will perhaps now help us see more clearly the complex and ambiguous relations which it maintains with political, ideological and cultural universalism.

IV.

The concept of universalism, which is to say a discourse applied to all humankind and not reserved to a fraction-ethnic or other-of the latter, has an equally ancient history.

What I called the metaphysical revolution, which extends from the fifth century $\mathrm{BC}$ to the seventh century AD, was based simultaneously on 
the tributary mode of production and the domination of the metaphysical ideology of the age. ${ }^{13}$ That Confucius, Buddha, Zoroaster are situated in the same century, about 500 years BC, that two centuries later Hellenism produced the synthesis of cultures of the Middle East, thus preparing the terrain for Christianity and Islam, these important facts constitute for me manifestations of this universal aspiration. It nonetheless remains defined within the setting of the tributary society that determines its upper reaches and limits. My thesis on this essential point is that the ideology of metaphysical alienation fulfilled in pre-capitalist societies a dominant function in the reproduction of the legitimacy of power, and that economic life was subjected to the logic of this dominant function. Here, power was the source of wealth, a relationship later inverted by capitalist modernity.

The grand universalism of the tributary age conquered enormous spaces which constituted themselves into distinct cultural areas, but none among them was able to impose itself on the entire planet. One might therefore be tempted to read the history of the two millennia that preceded the formation of capitalistic modernity as those of, on the one hand, the class struggle within the tributary social systems in the manner of Marx, and, on the other hand, of the "conflict of cultures" (religions and civilizations) à la Huntington perhaps (with all requisite reservations about the simple and superficial theses of this sociologist of Foreign Affairs). One is bound to assert that the conflicts of the time were far from assuming this dominant cultural dimension. Within the large cultural spaces in question, numerous and diverse political authorities shared and competed for control of the tributary extraction of surplus and their conflicts are those that, in fact, occupy center stage. Even the Crusades, so often presented as an epic battle between Christianity and Islam, were in fact "Frank wars" (as they were called by the Arabs at the time) conducted by feudal lords of the European periphery (mainly France, England and Germany) as much against Byzantium as against the Khalifate. These can be seen as an offensive by an ascendant periphery against the center (Hellenistic Byzantium and the Khalifate) dominant at the time.

The chapter of this phase of universalism has in any case been closed. "The human being makes his history" constitutes the new central tenet of modern universalism. Capitalist expansion has conquered the planet. However, this economic conquest has been far from homogenizing, and has, on the contrary, exacerbated the polarization of wealth. Modern universalism confronts a challenge to which it cannot answer from within its existing framework founded on the accumulation of capital.

The human being that is proclaimed to make his history is, as a result, the European and European alone. Eurocentrism,- - this particular distortion of ideologies and perspectives of the dominant world-is not one among other manifestations of the "conflict of cultures." It is the expression of the contradiction proper to the polarizing expansion of globalised capitalism. Eurocentrism is, as a result, a modern product, a fabrication that goes back again to the 18th century, concomitant with the age of Enlightenment. ${ }^{14}$ It has nothing to do, for example, with the vision which Western Christians of previous ages made of "infidels," Moslem or others. I developed these theses elsewhere concerning the multiple manifestations of eurocentrism, its mythological constructions concerning either the Greek ancestor (and Prometheus), or Christianophilia (the attribution to Christianity in general, or, for example, to Protestantism in particular, in the manner of Weber, specific and particular virtues that all other religions-confused with the "other," the "oriental" don't possess) or, in short, pure and simple racism.

The globalisation of real existing capitalism, that is to say of a polarizing system, does not have much to do with its cultural dimensions brought out by the discourse on "the westernization of the world." Technocrats of the system will always have some trouble understanding that the "global village" is a hollow expression. In fact, behind "westernization" there is in reality a real domination by the culture of capitalism. If I put quotation marks around "westernization" it is because the term is misleading. In fact, the dominant culture of the modern world is not "western," but capitalist in the sense that the center of gravity around which it is constructed is the economic alienation proper to capitalism. This fundamental character is not inherited from the European past; by inventing modernity Europe broke with its own past.

Nevertheless, the culture of capitalism has been unable to take root in the periphery because the latter are victims of world polarization, the very core of our problem. On the one hand, the main aspect of this culturecommodity alienation-is accepted without question. Protests against it are more pronounced in the richer societies of the center than among the poor of the periphery whose peoples aspire to a little bit of this consumption of 
which only the privileged can see the limits. But on the other side, the other aspects associated with this culture-the universal values of capitalism (spirit of enterprise, respect for the law, plurality of opinion) as those of its alternative socialist critique (overcoming commodity alienation, democracy with a social content) - are not generally accepted with ease. Polarization deprives them of all their positive content.

Therefore, depending on the time and local conditions, traumatised societies of the periphery will sometimes lean toward the adoption of values of the capitalist culture in question (democracy and the spirit of enterprise) or of their socialist critique. The disappointment and chaos that unfailingly follow on the failure of the attempts of the liberal bourgeois (or para-socialist attempts) result from the polarization that erases potential progress. This is the case in our moment of crisis, and religious fundamentalism as well as the resort to ethnicism are manifestations of it. The dominant system then tries to accommodate these returns to the past, which do not threaten the real domination of capital in any way, through light and sweet talk in praise of "diversity." This facile discourse of post-modernism ignores that there are different species of diversity. There is that which focuses on the future and calls for the plurality of the creative faculty for a future that lies beyond capitalism. There are also those sterile variants which focus on past heritage. In one hand you can brandish the symbol of your diversity (the Koran, or the flag of an ethnic group for example), so long as in the other hand you hold a bottle of Coke.

$\mathrm{V}+$

The internal contradiction of capitalist modernity therefore sets the economic dimension of polarizing globalisation against the political project of autonomy of nations of the periphery aspiring to "catch up." Historically, this contradiction was either exacerbated or attenuated depending on conjunctures, as was the case in the post-Second World War period marked by systems of regulation of the expansion of the market both at the national level and at that of international interdependence.

Three systems then occupied the center stage from 1945 to 1980-1990: the welfare state in the capitalist countries of the center, Sovietism in the East and populist national projects in the Third World. ${ }^{15}$ Each of these systems was based on its proper logic of strong regulation of markets, even to the point that the second (the Sovietism) nurtured the illusion of having reduced the sphere of intervention of the market to almost nil. ${ }^{16}$ At the level of globalised interdependence, systems conceived at Bretton Woods for the management of the international monetary system and within the context of the UN negotiations concerning trade and investments (notably within the UNCTAD), were also systems for the regulation of globalisation. Countries of the East, without receding into autarky (except when imposed from the outside, as was the case with China from 1950 to 1972), pretended to master their external relations again to a greater degree.

These forms of regulation brought about a generalized upsurge in economic growth and the period witnessed historically unprecedented growth rates in the three regions of the global system: the West, the East and the South. The negative assessment of the period by extremists of neoliberalism-the society of Mont Pèlerin - that speaks "of the failure" of models of the time, or of their "irrationality," is a completely ideological judgment (in the worst sense of the term) negated by the facts.

The regulations in question did not attenuate the fundamental contradiction of the system between the expansion of the accumulation of capital and the entrenchment of democracy. In the welfare state of the West, the practice of political democracy has been scrupulously respected to a previously unknown degree. But this political democracy was not social except in the sense that it was accompanied by the extension of social rights (type of social security) that avoided the socialization of the control of production as such. It therefore ended up with a manipulative and depoliticizing "massification" that gradually eroded the sense of democracy. In the countries of the East and the South, regulations put in place were also socially oriented in that the economic growth they engendered benefited, to varying degrees, wide segments of the masses. These were accompanied by a nearabsolute non-democratic policy. This forceful clamp-down on plurality was legitimized by discourses claiming it was necessary to "develop first," with democracy to follow in an almost spontaneous fashion. Official ideologues of Sovietism, theoreticians of Latin American "desarrollismo" and politicians at the service of the western powers (symbolized for example by Huntington) were in perfect agreement on this point.

The overall result was therefore the reinforcement of commodity alienation and the destruction of the natural environment. The hopes that the 
systems bred in the East and the South would be able to erase the heritage of polarization were also gradually erased, even though at one time and in certain areas they made it possible to reduce the impact of this polarization inherent to capitalism and "really existing socialism." Fatally, therefore, illusions vanished, systems were eroded, their legitimacy weakened, enabling the contradiction accumulation/democracy to resurface. The three systems of regulation and the one which operated at the global level to articulate their efficiency attained their historic limits. Their erosion therefore produced an upset in the relationship of social forces for the benefit of capital and the triumph of neoliberalism of the society of Mont Pèlerin. Contrary to the theoretical affirmations of this sect, this change wouldn't catapult the entire global system toward unprecedented heights, but on the contrary, encapsulate it in a declining spiral of endless crisis.

The challenge cannot be met by a "return to the past," a "remake" of previous forms of regulation. This does not take into account the critical reading of the post Second World War period that I have just proposed as well as consider the major changes, at all levels, produced by the "success" of the half century of the post-war period (industrialization of the peripheries, democratic aspirations, the questioning of commodity alienation, awareness of environmental degradation, new forms of the law of value, moves beyond manufacturing and Taylorist industrialization etc.). These are the new challenges. They can only be met by looking ahead, toward the future, without nursing a nostalgia for the past, recent or distant.

The collapse of the systems of regulation of the post-war period, which had attained their historic limits, opened a period of crisis of capitalism. The unbalanced power relations in favor of dominant capital, represented by the transnationals, yielded a meaningful rise in the profit margin. This was only made possible on the basis of relatively stagnant global demand, or even contraction, as a result of unequal distribution of income. I dwelt elsewhere on issues associated with the system of management of this crisis, ${ }^{17}$ legitimized by the ideological discourse of neoliberalism, generally called "competitive deflation" and whose constituent elements are well known: monetary policies, fixing of interest rates over those of inflation, budgetary policies aimed at reducing the deficit by curbing expenditure, flexibility of labor, and privatization.

These crisis management policies have a global dimension as they are deployed to enlarge terrain for financial investment, itself turned to as an alternative to the contraction of productive investments. The crisis manifests itself in surplus growth (produced by that of profit) which cannot find an outlet in the expansion of productive investment (for lack of dynamism in demand) in seeking an alternative financial outlet. What is known as financialization of the system (priority given to the protection of financial investment at the expense of productive investment) therefore constitutes a strategy for the management of the crisis in question. ${ }^{18}$ From this point of view, globalisation (it should be qualified as financial) becomes a strategy, rather than the product of an objective constraint. This strategy of financial globalisation is comprised of equally well known elements: the floating of exchange rates (which gives ample room for speculation), the management of the external debt of countries of the Third World and the former socialist bloc (and at that level the so-called policies of structural adjustment do not deserve their name, since their exclusive objective is crisis management aimed at subjecting the policies of countries concerned to the unique objective of debt serving even at the price of their de-industrialization), the external deficit of the United States. The interventions of the IMF aim to widen the field of this globalised financialization.

Results of this financial globalisation are already apparent. From 1980 onward the international financial transfers curve takes off and detaches itself from the growth of world trade and productive investments. To attribute this take-off to informatics, as is common, does not make much sense. The strength of data processing, which is only a means, certainly reinforces the possibilities of speculation, but it is not its reason; for that a surplus must necessarily exist that can not find a profitable niche in productive investment.

The major part of international financial movements concerns transfers between countries of the triad. This explains why no matter the comparative real interest rates (in the United States, Japan and Germany on which the European union is aligned) and the wide fluctuations of the exchange rate (the dollar to 80 yen or 380 yen!), the American deficit persists, destroying the theory that the meeting of supply and demand of money reveals the "true" exchange rate adjusted to the balances of payments.

Still, a portion of these flows head to the countries of the periphery. Floating capital finds in the periphery opportunities for short-term invest- 
ment, making it possible to rifle laboriously accumulated local surpluses, as was the case during the "financial crises" of Latin America (Mexico in 1982, tomorrow Brazil?), of South Africa (following the movement of capital toward this country avoiding Southeast Asia since its crisis of 1997), and could be the turn of Russia and others tomorrow. These capital flows moved toward East and Southeast Asia. The motivations here were more diverse. Strong growth (in China, Korea, Southeast Asia) attracted capital there, nourished by the illusion of prosperity without risk. This strong growth, exceptional at the world level, was nonetheless due, to a large extent, not to deregulated opening up (as the World Bank Reports put it) but instead to the regulation maintained in this region through the management of national strategies. That these strategies were effective and intelligent in the long-run is debatable. Whether they attracted our sympathy or appeared negative in their social and political dimensions are different problems. The attraction of these funds for Asia was reinforced when, as from the 1990s, some of these countries (especially in Southeast Asia) equally took their turn in opening capital accounts. They found themselves further strengthened by the opportunities that would emerge in China and India with the envisaged opening of their accounts.

The influx of capital into Southeast Asia led to a kind of crazy inflation in real estate and stock markets. As the good economists of the region had predicted way back in 1994, this was bound to lead to a financial crisis. These nonconformist economists were ignored; the World Bank and IMF rejected their forecasts through stupid reports of command optimism until the collapse!

The so-called Southeast Asia crisis marks a turning point in the future trend of the management of globalisation. ${ }^{19}$ It announces the coming collapse of globalised management of the financial surplus of capitalism in crisis. It is interesting to observe that national governments in the region in question reacted in a manner that has for the first time disproved the certainties of the G7 and the institutions at its service. China and India are, in effect, no longer considering opening their capital accounts; Korea and countries of Southeast Asia are looking in the same direction, that of the restoration of national control over the movements of capital; countries of Latin America and some others, possibly including Russia, could imitate them; and the Non-Aligned movement (NAM) could become "Non-
Aligned on Globalisation." The G7 was not insensitive to this real danger that threatens to put an end to financial globalisation, retransferring the risks of the depreciation of capital into the triad. Did the G7 not acknowledge that it was necessary to "regulate" international capital flows barely two weeks after the crisis exploded? A few days earlier the same word, "regulation," was still forbidden. Whoever used it risked being labeled blinded by Communist nostalgia. The chief economist of the World Bank, Stiglitz, followed in these same footsteps in suggesting a new formula for crisis management called a "post-Washington consensus." Of course these key persons responsible for globalised management initiated only a counter-offensive to enable them remain masters of the game. It is necessary to save capitalism from neoliberalism, declares George Soros.

Indeed the global economic war has begun. The crisis of Southeast Asia, and especially that of Korea, is in fact, in its financial dimension, a minor crisis similar to the many witnessed by Great Britain and France after the war. It has been observed that the "fundamentals" proper to the countries of Asia concerned have remained healthy, and, measured in terms of deficit in proportion of the GDP or durability, the Korean crisis is less severe than that of the United States. And yet dominant capital—backed by the diplomacy of the United States and Japan - is not content with reform proposals appropriate to the problems through the reorganization of the local banking and financial systems for example. They try to seize the opportunity to dismantle the Korean productive system no less, under the pretext that the latter would be dominated by monopolies! The same logic should bring the IMF to oblige the United States-whose crisis is more severe and more profound-to sell Boeing for example (a monopoly, it would appear) to its European competitor, Airbus (also a monopoly!). Mr. Camdessus, irrespective of his French nationality, would be fired by Clinton the next hour if he were to propose a similar solution!

The collapse of the financial globalisation strategy opens a new phase of serious international conflicts. Those who, while analyzing financial globalisation, concluded that the latter would in the end be the harbinger of geopolitical conflicts and perhaps a return of nationalistic affirmations of national sovereignty, were they wrong to have understood the nature of the crisis before others? Of course, the conflicts in perspective are not "conflicts of cultures" à la Huntington, but instead, as always, conflicts of societies. The 
major conflict that would probably erupt quickly is that which has already ranged the dominant powers of the triad against those who govern societies of the first order of the periphery. But we can also foresee an amplification of contradictions within the triad, on whose development will depend, to a large extent, the dynamics of the construction of the European Union.

Will these conflicts retain a purely mercantile dimension? Or will the upsurge of the social struggles engendered by the collapse of the management policies of the crisis raise them to significant social and meaningful alternative policies? In Europe, these struggles will necessarily center around the project of the Union to possibly give it a progressive social content. ${ }^{20}$ Also, in China, they will lean toward one direction or the other of the national project. ${ }^{21}$ I refer back to what I wrote about the various scenarios concerning these two regions whose evolution will play, it seems to me, a crucial role in the next stage both of social transformation and globalisation.

In any case, we are entering into a period of conflict and the rise of social struggles. The neoliberal policy of "competitive deflation"-globalisation unilaterally regulated by transnationals-financialisation is already in crisis. In record time, it has seriously aggravated all social problems that peripheral capitalism had never seriously tackled hitherto: the agrarian question and amplified poverty, social dislocation and exclusion at an unprecedented level, marginalization of countries and entire continents. In the developed capitalist centers, it has brought job insecurity and permanent unemployment back to the fore. As can already be seen, major social movements, as those of the landless in Brazil or unemployed in France have assumed the dimension of a political challenge. These social struggles are bound to strengthen and spread because the inevitable devaluation of capital will give rise to violent conflicts over who pays the bill. The G7 and its instruments (including the military strength of the United States and the media at its service) are already trying to shift the weight of the crisis to the popular classes in countries of East and South Asia. They have already been able through the reduction of the prices of raw materials (oil and tropical agricultural products) to further marginalize the most vulnerable countries of the periphery and to shift onto their peoples the burden of impoverishment of their economies. Tomorrow, they will probably try to shift part of the bills to the pensioners in the private systems of pensions, (in the United States, in Great Britain especially), because it is less difficult to reduce retirements than wages!

Will it be possible, in such conditions, to develop strategies for common struggles globalised in their own way? Will the reconstitution of a reserve army in the centers themselves, make it possible to create a new popular internationalism? Will the conjunction between the struggles for the democratization of political and social systems in the peripheries and the rejection of the G7 crisis management plans make it? The answers to these questions will depend on the development of the people's struggles, which, in the final analysis, are the subjects of history.

Certainly it is not useless to propose possible alternatives in order to "move beyond the crisis," alternatives to the "globalisation" mentioned earlier. The debate around these questions will certainly help the social movements to see more clearly, to formulate more effective strategies. I would say, without mincing words, that it is not difficult to conceive these alternatives on the basis of principles that seem obvious: the regulation of markets at all levels making it possible to return to full employment and the reduction of reserve armies in the periphery, the reorganization of capital markets with the prospect of channelling the latter to productive investment, rebuilding of financial and monetary systems in view of organized rationalization plans creating conditions for a new negotiated globalisation, the democratization of societies and the reinforcement of basic human rights. These changes would certainly require the establishment of appropriate institutions, both at the national level (by inventing new forms of state intervention) and at the regional and international levels. It is not difficult to conceive the modalities on which to base the latter institutions called forth to substitute for the World Bank, the IMF, the WTO, nor reforms that could relaunch the UN (in the management of trade and transfer of capital and technology, through a regenerated UNCTAD, for the security of peoples and nations). These alternatives are inscribed in the perspective of the construction of a polycentric world, assuring peoples and nations levels of autonomy that would enhance democratic and social progress.

Difficulties are not situated, in the main, at the levels of "technicality" of the mechanisms and institutions to be conceived. They are situated at a totally different level: What social and political forces are in a position to impose it? 
VI.

We now come to the conclusion of this presentation of challenges, with a fundamental question: how is history made?

I am not one of those for whom history is a process without a subject. Whether the determinism in question is one of the dominant conventional ideology, expressed in terms of implacable economic "laws" and in the comical case of the neoliberal sect in those of the self-regulated, omnipotent "market," or be it those popularized by the vulgate of Soviet Marxism, the "diamat," (the Russian reduction of two qualifiers: dialectical and materialist) or formulated in the more elegant manner of "over-determination" in the manner of Althusser. I belong to those for whom history is a process set in motion by active subjects. This immediately raises two sets of questions: who are the subjects, and how are they active?

Marx was interested in these issues. In the 1848 Manifesto, he described them in terms of rival classes defined by the mode of production: slaves and masters, serfs and lords, proletariat and bourgeois. Others have defined them in no less contrasted terms of rival peoples or nations. In fact, the two sets of conflicts - of classes and nations - take center stage. The history of the last two centuries can be interpreted as animated by the workers' struggle and the struggle of nations victimized by world polarization. In other words, to the struggles waged by "antisystemic" forces since the system is both that of exploitation of labor and inequality of nations. In the vision of historic Marxism of the $2^{\text {nd }}$ and $3^{\text {rd }}$ international, the proletariat became the obliged gravedigger of capitalism. In that of imperialism and Third World nationalism, the dominant people or their dominated victims fulfilled similar functions as major actors in history.

The concept of the subjects of history which I propose is not fixed. These movements are diverse, and do not become active and decisive except for a time, determined by the movement of the contradictions of the system. Classes, segments of classes, groups of intelligentsia, peoples and nations occupy the center stage and determine the general orientation of the system particularly in the times of crisis, of disruption of the logic of its expansion. For example, I would say that the people of Vietnam occupied this center stage when, in the liberation struggle, they were able to overcome the American power and made the American people themselves begin to doubt the moral order on which this power claims to justify its legitimacy.
The determinant active subjects of history are rarely "known" in advance. History is for that reason unforeseeable. Fortunately, neither the history of an individual, nor that of the society is "programmed," inscribed on Divine Tables, or recorded in genes.

This uncertainty must in turn be explained. I propose at this point the thesis that I described as "underdetermination" (as opposed to "overdetermination" of the Marxo-Althusserian vulgate). ${ }^{22}$ In this spirit, I propose to analyze the logics proper to each of the constituent processes of social reality, and to study their specific concrete contents, be it the logic of capitalist accumulation (for modern times), that of a particular type of system of power, or those of ideological and/or religious systems. These logics are not, a priori, either fatally complementary (in conformity with the concept of over-determination of the market discourse), nor necessarily contradictory. A particular consistency is always finally produced in one way or another, determined by the actions of subjects of history. This coherence is ensured by the dominance of a specific logic at a given moment and the subjugation of others. One does not know in advance which of the various possibilities will impose itself. My definition of human liberty is situated in the choice that societies make and that determines the particular coherence in a given concrete society, at a given moment of history. It is not therefore liberty conceived without constraints. Such is my reading of Marx and Engels: human beings make their history, but within the context of objective constraints.

The choice between different possible alternatives - always diverse, but in limited numbers - is permanent. But it becomes decisive in its long-term consequences in certain circumstances which can be said for that reason to be situated at the crossroads. There is certainly some danger in saying that a particular time has a particular nature. I will nevertheless, have the audacity to advance the hypothesis that we find ourselves in such a moment of history, where the better and the worse are both equally possible.

My basic argument is that capitalism, in its development, has passed through two successive phases and that the second has exhausted its possibilities.

During the first phase, that of the mercantilist transition, capitalist social relationships did not generally express themselves through the subjugation of free labor in an enterprise organized specifically to extract more absolute or relative surplus value. The biggest proportion of producers 
were at this time the owners of the necessary technical knowledge and even further, to a large extent, formal proprietors of the means of production (which were reduced to handicraft tools). They were subjugated to capital through the market dominated by the capitalist merchants. Putting out was therefore the formula by which merchant capital exploited the labor of small producers. In some cases these were assembled under the same roof of a manufacture which made it possible to control their use of time more thoroughly. The period-be it called that of mercantilist transition or that of the first phase of capitalism - is also the one that Marx analyzed in terms of primitive accumulation: characterized by the violent dispossession of producers (the enclosures were among the means which have been studied in that frame) necessary for the creation of a "free" labor force forced to sell its labor in the form of wages, or by "putting out." The articulation of political power and expansion of markets was at the center of the mechanisms of accumulation of the period. Contrary to the imagination of conventional economics, capitalism is not synonymous with "market." Marx, Polanyi and Braudel have discussed this issue, and produced realistic analyses of this politics/economy relation specific to capitalism that dominant conventional social thought ignores. ${ }^{23}$

The phase was at the same time that of conflict between the logics of tributary power-in this case feudal in its European form-and those of capitalist power. This was a conflict regulated during the mercantilist transition by the absolute Monarchy of the Ancien Régime and finally resolved with the triumph of the bourgeois revolutions of the Netherlands, England and France.

The second phase is that which I qualify as the full-fledged form of capitalism, simultaneously founded on the bourgeois system of political power (liberal constitutions based on suffrage) and on the industrial revolution. The means of production become a collection of equipment (machines and buildings) outside the reach of artisanal property. Whereas the exploitation of labor had been present throughout the history of humanity, mainly based on the control of access to natural means of production (basically land), henceforth it would be control of this equipment that determined the major form of ownership. Still, over this long period workers remained repositories of the knowledge required to operate the machines. They were skilled laborers close to the engineers, who were few at the time. It took more than one century-until the Taylorism invented in the United States in the 1920s - for the workers to be massively dispossessed of their qualifications. These skills were transferred to an external social body, that of technicians, engineers and organizers of production.

This phase witnessed the establishment of the fundamental character of capitalism, the proletariat/capitalist conflict. It therefore witnessed the birth and the development of the workers' parties and their struggles to extend the rights limited by bourgeois democracy. Simultaneously the mechanisms of the reproduction of capital assumed autonomy, giving the impression that the "market" dictates its law to both the workers and the employers. I say "impression" because, in fact, these forms of expanded production do not exist outside the social relations in which they are embedded. Therefore, really existing capitalism is unthinkable outside politics and the state. This is why primitive accumulation endured this second phase of capitalism. Primitive accumulation is not specific to the prehistory of capitalism alone; on the contrary, it constitutes a permanent aspect of it. Such is the expropriation which gave birth to oligopolies, whose episodic "anti-trust" promises have never been implemented conscientiously. It is also from the industrial revolution that the center/periphery polarization reached the catastrophic dimensions that I evoked earlier. However, this polarization was not produced by the spontaneous activity of the market, but more so by the political interventions of the states concerned. For this reason, I qualify imperialism as the permanent stage of capitalism. Unequal exchange, particular to this long $19^{\text {th }}$ century, was one of the main forms of this permanent primitive accumulation.

There are many signs indicating that capitalism has entered a third phase of its development, perhaps the phase of its decline: the ongoing scientific and technological revolution, computerization and robotics, decentralization of productive systems (delocalised production, managed from a distance, sub-contracting, etc.), tertiarisation and quarterisation of economic life and the decline of the share of industrial manufacturing.

The dominant discourse concerning these transformations proposes that this last transformation by definition brings progress. This appears a simple and naive thesis once one realizes it is not technique that commands history, as McLuhan asserts, but the struggle for the control of the latter, and that the economics which sets the system in motion is itself encapsulated in 
social relations. The conjunction of these transformations, whose importance I do not overlook, only indicates that we are indeed at the crossroads and that the alternatives have to do precisely with social relations ignored in the dominant discourses.

The development of historic capitalism is that of the continuous exacerbation of its three contradictions: commodity alienation, global polarization, destruction of the natural base. ${ }^{24}$ None of these ongoing changes mechanically imply the reversal of the trends. But each of them could make this reversal possible.

Informatics and computerization on the one hand, the growing centralization of capital on the other, are challenging the concept of value and announce its possible withering away. The near disappearance of direct labor as a result of robotized work processes abolishes the autonomy of every singular chain of production to make it an indissociable element of social production taken as a whole. Besides, the new forms of re-skilled labor amplify interdependence in production, abolish the concept of competitiveness at the level of the productive unit while endowing it with the power that belongs to the society of citizens. This is a concept Marx imagined more than a century ago, announcing the end of the diktat of value and which he described as "general intellect" becomes reality. ${ }^{25}$

This evolution makes it possible to consider new social relations emancipated from commodity alienation, of which the income of citizenship could constitute the first step, starting the long transition to socialism defined as the social mastery of production. But it could equally be maintained in the corset of a renewed alienation, legitimizing inequality both in the distribution of the social product and in the organization of power at all levels, from enterprise to state. In this hypothesis production would remain regulated in appearance by the "market," in fact by coalitions of dominant capitalist interests. More than ever this capitalism of the third age appears like the antithesis, and not the synonym, of the market. More than ever its reproduction would require the continuous and active intervention of the state, of policies manipulated to serve its interest and the reduction of democracy to the status of decorative rhetoric.

The decline of industrial production in the centers of the system and the explosion of the so-called tertiary and/or quaternary activities are themselves ambiguous. Some of these activities, dictated by scientific progress, potentially hold promise for a better organization of society. One could easily include in this category the more effective equipment, progress in medicine, expansion of knowledge and education. But many other such activities are nothing other than means of organizing the wastage of the surplus generated by the increased productivity of social labor. This wastage is necessary in order to facilitate the reproduction of unequal distribution of income. It also exacerbates mercantile forms of economic management. The "costs of selling" - advertisement and others-are the expressions of such bloated capitalism in decline. One sees that the relative decline of manufacturing industry does not bring the pre-industrial world. Economic activities-including those related to the tertiary and the quaternary sectors-remain more than ever controlled by oligopoly capital whose centralization continues endlessly. Here again one finds capitalism is unthinkable without politics at its service.

At the level of the global system, ongoing changes are bound to further exacerbate polarization. The "five monopolies," which I explained earlier, are at the root of this aggravation of the trend toward inequality, in spite of the successes of industrialization in the peripheries of the system. However, these monopolies have "extra economic" dimensions ignored by "pure economics." Their obvious political dimensions, which the arrogance of military superpower calls to mind each day, illustrate once again that the economy is embedded in social relations in which politics constitutes the tip of the iceberg.

In this perspective, capitalist expansion could continue for a long time while drawing from the gigantic reserves I mentioned earlier, by organizing a kind of putting-out system at the global level. This system, which much resembles a kind of apartheid at the world level, maintained by military violence, would certainly have meshed perfectly with the temperament of the departed Adolf Hitler! The global system of capitalism of the third age therefore runs the risk of being nastier than those of previous phases of its development; it also stands to reason that this possibility is not the only one. Peoples and nations of the periphery no longer accept the destruction that polarization represents for them. Bridges can be constructed by establishing an active solidarity between this refusal, on the one hand, and the democratic aspirations of peoples of the centers on the other. Systems of regulation at the global level might then enhance the current potential to 
bring positive changes and the progressive reduction of polarization, as well as the construction of a pluricentric world, and the conditions for the long transition to global socialism.

Actually existing capitalism is not the chimerical model of the imaginary of the sect of Mont Pèlerin. It has always been a political and social system in which competition between the owners of dominant capital is embedded, although the competition may take different forms. Power and politics are always there, behind the market. "Normal" reproduction of capital and the so-called forms of primitive accumulation (which imply political and social violence) are always linked. The prevalent rhetoric is used to separate these two faces of Janus, describing as "corrupt" or "Mafioso," attitudes which are nothing more than the extreme expression of normal competition (which in fact implies the exercise of violence and the abusive use of power). These explosions of rhetoric aimed at legitimizing "good capitalism" replicate themselves regularly, and curiously in moments-such as ours-characterized by the exacerbation of the permanent contradictions of capitalism.

The contradiction from which I began is that between the economic logic of capitalism and globalisation and the emancipatory, democratic aspirations of the popular classes and nations victimized by capitalism. This contradiction remains far from resolved. So long as this contradiction is surmounted by the dominance of the first of its poles, capitalist society will become increasingly barbarous. However, if the second of its poles manages to win out, even if gradually, then the third age of capitalism will become that of its decline, opening the long transition to socialism. ${ }^{26}$

\section{FOOTNOTES}

1. See my critique of the theory of the self-regulating market in S. Amin, Spectres of Capitalism: a critique of current intellectual fashions, Monthly Review Press, NY 1998, chap. 8. Cf. Bernard Guerrien, L'économie néoclassique, Repères, La Découverte 1996; Giorgio Israël, La mathématisation du réel, Le Seuil, 1996. Hakim Ben Hammouda, Les pensées uniques en économie, L'Harmattan 1997.

2. Samir Amin, Spectres of Capitalism, op cit., chap. 2.

3. Karl Polanyi, The Great Transformation, Beacon Hill, Boston 1994. First edition 1944.

4. See my views on modernity and critique of post modernism in Spectres of Capitalism, op cit., chap. 6, bibliography at the end of the book.
5. Samir Amin, "The Ancient World System versus the Modern Capitalist World System," Review, XIV, 3, 1991, pp 349-385 (bibliography appended to the article).

6. Cf. S. Amin, "History Conceived as an Eternal Cycle," Review, XXII, 3, pp. 291 326.

7. On the globalised law of value, see S. Amin, Les défis de la mondialisation, L'Harmattan, Paris 1996, chap. III.

8. Samir Amin, Capitalism in the Age of globalisation, Zed, London 1997, chap. 1.

9. Ref. Note 7.

10. Arthur Lewis, "Economic Development with unlimited supplies of labor," The Manchester School, May 1954.

11. Ref. note 7.

12. Yoshikara Kunio, The Rise of Ersatz capitalism in South East Asia, Manila University Press, 1988

13. Samir Amin, Eurocentrism, Zed Press, London 1989, Part one.

14. Ibid, Part two.

15. Samir Amin, (editor), Mondialisation et Accumulation, L'Harmattan, Paris 1993, Introduction.

16. The formal opposition between "market economies" and "centrally planned economies" should be qualified. See. S. Amin, Spectres of Capitalism, op cit., chap. V.

17. Cf. S. Amin, La gestion capitalist de la crise, L'Harmattan 1995; S. Amin (ed.), Mondialisation et Accumulation, op cit; and S. Amin, Capitalism in the age of globalisation, op cit., chap I, II, V.

18. Samir Amin, “The challenge of globalisation," RIPE, III, 2, Summer 1996, pp 219 230.

19. Jomo Sundaram (ed.), Tigers in Trouble, Zed, London 1998, contributions of Jomo K. S., Walden Bello, Chang Ha-Joon and others. Also, in Mondialisation et Accumulation (op cit.), the contributions of Suthy Prasartset and Georges Aseniero.

20. Samir Amin, Capitalism in the Age of Globalisation, op cit., chap. VI.

21. Samir Amin, The Future of maoism, Rainbow Publ, Delhi 1998 (pp. 133-144).

22. On underdetermination, see S. Amin, Spectres of Capitalism, op cit., chap. III.

23. See my views on the conceptualization of social systems and of capitalism by Marx, Polanyi and Braudel, in "The challenge of globalisation," RIPE, op cit.

24. Samir Amin, Les défis de la mondialisation, op cit., conclusion, Section I.

25. Samir Amin, Spectres of Capitalism, op cit., chap. V.

26. Samir Amin, Les défis de la mondialisation, op cit., conclusion. 